\title{
Mice Lacking the Serotonin Transporter Exhibit 5-HT IA Receptor-Mediated Abnormalities in Tests for Anxiety-like Behavior
}

\author{
Andrew Holmes*,', Rebecca J Yang', Klaus-Peter Lesch ${ }^{3}$, Jacqueline N Crawley' and Dennis L Murphy² \\ 'Laboratory of Behavioral Neuroscience, National Institute of Mental Health, NIH, Bethesda, USA; ${ }^{2}$ Clinical Psychobiology, Department of \\ Psychiatry and Psychotherapy, University of Würzburg, Germany; ${ }^{3}$ Laboratory of Clinical Science, National Institute of Mental Health, NIH, \\ Bethesda, USA
}

\begin{abstract}
The serotonin transporter (5-HTT) regulates serotonergic neurotransmission via clearance of extracellular serotonin. Abnormalities in 5$\mathrm{HTT}$ expression or function are found in mood and anxiety disorders, and the 5-HTT is a major target for antidepressants and anxiolytics. The 5-HTT is further implicated in the pathophysiology of these disorders by evidence that genetic variation in the promoter region of the HTT (SLC6A4) is associated with individual differences in anxiety and neural responses to fear. To further evaluate the role of the 5-HTT in anxiety, we employed a mouse model in which the 5-HTT gene (htt) was constitutively inactivated. 5-HTT -/ - mice were characterized for anxiety-related behaviors using a battery of tests (elevated plus maze, light $\leftrightarrow$ dark exploration test, emergence test, and open field test). Male and female 5-HTT - / - mice showed robust phenotypic abnormalities as compared to $+/+$ littermates, suggestive of increased anxiety-like behavior and inhibited exploratory locomotion. The selective 5-HTIA receptor antagonist, WAY $100635(0.05-0.3 \mathrm{mg} / \mathrm{kg})$, produced a significant anxiolytic-like effect in the elevated plus maze in 5-HTT -/- mice, but not +/+ controls. The present findings demonstrate abnormal behavioral phenotypes in 5-HTT null mutant mice in tests for anxiety-like and exploratory behavior, and suggest a role for the 5- $\mathrm{HT}_{\text {IA }}$ receptor in mediating these abnormalities. 5- $\mathrm{HTT}$ null mutant mice provide a model to investigate the role of the $5-\mathrm{HTT}$ in mood and anxiety disorders.

Neuropsychopharmacology (2003) 28, 2077-2088, advance online publication, I0 September 2003; doi: I 0. I038/sj.npp. I 300266
\end{abstract}

Keywords: serotonin; serotonin transporter; gene; mouse; anxiety; 5-HT IA receptor

\section{INTRODUCTION}

A wealth of research implicates the brain serotonin system in the pathophysiology and treatment of mood and anxiety disorders (Charney et al, 1999). The cell membrane serotonin transporter (5-HTT) acts as a critical regulator of serotonin signaling, via reuptake of serotonin from the perisynaptic and synaptic space (Blakely et al, 1991; Ramamoorthy et al, 1993). Drugs which block 5-HTT activity act as antidepressants and anxiolytics (Ballenger, 1999; Stein and Berk, 2000; Kugaya et al, 2003). Moreover, there is evidence that abnormalities in 5-HTT expression or function may contribute to the etiology of depression and anxiety disorders. In drug-free patients, studies of postmortem brain tissue, living brain, and platelets have found

\footnotetext{
*Correspondence: Dr A Holmes, Laboratory of Behavioral Neuroscience, National Institute of Mental Health, Building 10, Room 4DI I, Bethesda, MD 20892-I375, USA, Tel.: + I 30I -496 4838, Fax: + | 30 I-480 ||64, E-mail: aholmes@intra.nimh.nih.gov

Received 19 March 2003; revised 03 June 2003; accepted 04 June 2003 Online publication: 9 June 2003 at http://www.acnp.org/citations/ Npp060903020 I I 6/default.pdf
}

evidence of reduced 5-HTT binding in affective disorders (eg Briley et al, 1980; Nemeroff et al, 1994; Malison et al, 1998; Willeit et al, 2000; Arango et al, 2002). There is also growing evidence that genetic variation in 5-HTT function may affect relative risk for emotional disorders. A common 44-base pair insertion/deletion functional polymorphism in the HTT (SLC6A4) determines levels of 5-HTT mRNA and binding sites, as well as serotonin reuptake (Lesch et al, 1996; Little et al, 1998; Greenberg et al, 1999). Individuals harboring the low-activity HTT variant show higher trait anxiety/dysphoria, and great neuronal responses to fear, and are at increased risk for depression than those without this variant (Lesch et al, 1996; Mazzanti et al, 1998; Greenberg et al, 2000; Murphy et al, 2001; Hariri et al, 2002; Caspi et al, 2003).

To further study the role of the 5-HTT in anxiety, we generated mutant mice in which the 5-HTT gene ( $h t t$, slc6a4) has been constitutively inactivated (Bengel et al, 1998). Previous studies have confirmed that 5-HTT null mutant mice exhibit marked alterations in serotonergic homeostasis. Thus, 5-HTT binding sites in brain are absent in 5-HTT homozygous $(-I-)$ null mutant mice and are 
reduced $50 \%$ in 5 -HTT heterozygous $(+/-)$ mutant mice (Bengel et al, 1998). 5-HTT -l- mice exhibit an absence of high-affinity, Na- and Cl-dependent, 3H-5-HT uptake in cortical or brainstem synaptosomes, while gross brain serotonin concentrations are decreased to $20-40 \%$ of normal levels in these mice (Bengel et al, 1998; Tjurmina et al, 2002). Loss of 5-HTT-mediated reuptake leads to prolonged clearance of serotonin in 5-HTT $-/-$ and 5 -HTT $+1-$ mice, as measured in the hippocampus using in vivo chronoamperometry (Montanez et al, 2003). As a result, basal extracellular serotonin is increased nine-fold in 5 -HTT $-I-$ mice and five-fold in 5 -HTT $+/-$ mice, as measured by zero net flux microdialysis in the striatum (Mathews et al, 2000). As a compensatory response to chronically elevated levels of extracellular serotonin, 5-HTT null mutant mice exhibit decreases in 5-HT receptor expression and function (Rioux et al, 1999; Fabre et al, 2000; Mannoury la Cour et al, 2001; Sora et al, 2001; Li et al, 2000, 2003; Holmes et al, 2002a). Despite downregulation and desensitization of $5-\mathrm{HT}_{1 \mathrm{~A}}$ autoreceptors, basal serotonin dorsal raphe neuron firing is reduced in 5-HTT null mutant mice, indicating a lack of adaptation to increased extracellular serotonin (Gobbi et al, 2001). 5-HTT null mutants also show relatively minor compensatory changes in other monoamine systems. Levels of norepinephrine, dopamine and their metabolites in 5-HTT null mutant mice are similar to those found in $+/+$ controls, as is the number of norepinephrine or dopamine transporter binding sites (Bengel et al, 1998; Zhou et al, 2002). How prolonged changes in serotonergic homeostasis impact anxiety-related behaviors in 5-HTT null mutant mice is the subject of the present investigation.

Behavioral phenotyping in our laboratory has shown that 5-HTT null mutant mice are normal on a range of measures of gross neurological and sensory ability, but exhibit reduced conspecific aggression, reduced home cage locomotor activity, abnormal depression-related behaviors, and altered responses to antidepressants (Holmes et al, 2002a, b). In addition, 5-HTT null mutant mice have been found to show abnormalities in reward-related and locomotor responses to psychostimulants (Bengel et al, 1998; Uhl et al, 2002), analgesic responses (Vogel et al, 2003), and REM sleep (Wisor et al, 2003). In the present study, 5-HTT null mutant mice were characterized for anxiety-related behaviors using a battery of tests (ie elevated plus maze, light $\leftrightarrow$ dark exploration test, emergence test, and open field test), as previously described (Holmes et al, 2003). Neuropharmacological studies of $5-\mathrm{HT}_{1 \mathrm{~A}}$ receptor compounds and phenotyping of $5-\mathrm{HT}_{1 \mathrm{~A}}$ receptor null mutation mice gene implicate this receptor in neural circuits underlying emotion (Griebel, 1995; Griebel et al, 1999, 2000; Olivier et al, 1999; Canto-de-Souza et al, 2002; Gross et al, 2002; Nunes-de-Souza et al, 2002). Furthermore, we have recently found that a functional polymorphism in the transcriptional control region of the human $5-\mathrm{HT}_{1 \mathrm{~A}}$ gene is associated with anxiety traits (Strobel et al, 2003). Thus, in order to study whether abnormal signaling at the 5$\mathrm{HT}_{1 \mathrm{~A}}$ receptor may contribute to an anxiety-related phenotype in 5-HTT null mutant mice, we assessed the behavioral consequences of pharmacological blockade of the $5-\mathrm{HT}_{1 \mathrm{~A}}$ receptor in the elevated plus-maze test for anxiety-like behavior.

\section{MATERIALS AND METHODS}

\section{Subjects}

Serotonin transporter (5-HTT) null mutant mice were generated as previously described (Bengel et al, 1998). Briefly, $3^{\prime}$ and $5^{\prime}$ DNA fragments encompassing exon 2 of the $h t t$ and with an overall length of $7.5 \mathrm{~kb}$ were inserted into the pPNT-neo replacement targeting vector, containing a neo and TK cassette under the control of the PGK promoter. A $1.1 \mathrm{~kb}$ BamHI/HindIII fragment was replaced by the $1.8 \mathrm{~kb}$ PGK neomycin-polyA expression cassette. In all, $129 \mathrm{R} 1$ embryonic stem cells were cultured, transfected, and subjected to double selection. DNA was digested with Asp718 and hybridized with a $3^{\prime}$ probe that recognized a $h t t$ sequence external to the construct. In addition, recombinant embryonic stem cell clones were identified by Southern blot analysis, with the use of a $5^{\prime} \mathrm{HindIII/BamHI}$ probe to confirm accurate gene targeting. Embryonic stem cell clones were microinjected in $\mathrm{C} 57 \mathrm{BL} / 6 \mathrm{~J}$ blastocysts to obtain chimeric progeny. Chimeric males were mated to C57BL/ 6J female mice and pups genotyped by Southern blot analysis of tail biopsies to confirm germline transmission. For behavioral experiments, the 5-HTT mutation was backcrossed into a C57BL/6J genetic background for eight generations. 5-HTT mutant mice and $+/+$ littermate controls were derived from 5 -HTT $+I-\times 5$-HTT $+I-$ matings, and are viable, and reproduce and develop normally.

\section{Behavioral Testing}

Behavioral testing was conducted on two separate cohorts of mutant mice and their littermate controls, all bred and raised at the National Institute of Mental Health (Bethesda, $\mathrm{MD}$, USA). At weaning, mice were group housed with samesex littermates, in a temperature- and humidity-controlled vivarium, under a $12 \mathrm{~h}$ light/dark cycle (lights on $0600 \mathrm{~h}$ ). Cohort 1 was assessed on an anxiety-related test battery and consisted of 135 -HTT $-/-, 155$-HTT $+/-$, and $15+/+$ female mice, and 135 -HTT $-/-, 185$-HTT $+/-$, and 13 $+I+$ male mice. Male and female mice were tested separately. Over a 4-week period, mice were tested on the emergence test, light $\leftrightarrow$ dark exploration test, elevated plus maze, and open field test, in that order. To control for the potential effects of prior test experience on anxiety-like behavior (Holmes and Rodgers, 1998), each mouse was tested in each behavioral test. In cases of a failure of the test equipment or poor physical condition of the animal on the day of testing, data were removed from the analysis. Cohort 2 was tested for the effects of WAY 100635 in the elevated plus maze and consisted of 435 -HTT $-/-, 45$ 5-HTT + I-, and $45+/+$ female mice. For both cohorts, subjects were 3-7 months of age. To ensure that experimenters remained blind to genotype, subjects were only identified by individual ear tag numbers until the completion testing. Testing was conducted during the light phase of the light/ dark cycle (0600-1800 h). Mice were transported to the test room at least $1 \mathrm{~h}$ prior to testing to allow for acclimation. The test equipment was cleaned with a weak ethanol solution and dried between subjects. All experimental procedures were approved by the National Institute of 
Mental Health Animal Care and Use Committee, and followed the National Institute of Health guidelines outlined in 'Using Animals in Intramural Research.'

\section{Elevated Plus Maze}

The elevated plus maze was conducted as previously described (Lister, 1987; File, 2001; Bale et al, 2002; Holmes et al, 2002b, 2003). The apparatus (San Diego Instruments, San Diego, CA) comprised two open arms $\left(30 \times 5 \mathrm{~cm}^{2}\right)$ and two closed arms $\left(30 \times 5 \times 15 \mathrm{~cm}^{3}\right)$ that extended from a common central platform $\left(5 \times 5 \mathrm{~cm}^{2}\right)$. A small raised lip $(0.5 \mathrm{~cm})$ around the edges of the open arms prevented animals from slipping off. The apparatus was constructed from polypropylene and Plexiglas (white floor, clear walls) and elevated to a height of $38 \mathrm{~cm}$ above floor level. Mice were individually placed on the center square, facing an open arm, and allowed to freely explore the apparatus under an even overhead fluorescent lighting $(200 \mathrm{~lx})$ for $5 \mathrm{~min}$. Open and closed arm entries (all four paws in an arm), time spent in the open arms and rears within the closed arms were scored by an experienced observer (intrarater reliability $>0.90$, as previously determined; Holmes and Rodgers, 1998) using behavioral scoring software (Hindsight, Scientific Programming Services, Wokingham, UK).

\section{Light $\leftrightarrow$ Dark Exploration Test}

The light $\leftrightarrow$ dark exploration test was conducted as previously described (Crawley, 1981; Mathis et al, 1994; Holmes et al, 2002b, 2003). The apparatus consisted of a polypropylene cage $\left(44 \times 21 \times 21 \mathrm{~cm}^{3}\right)$ separated into two compartments by a partition, which had a small opening $\left(12 \times 5 \mathrm{~cm}^{2}\right)$ at floor level. The larger compartment $(28 \mathrm{~cm}$ long) was open-topped, transparent, and very brightly illuminated by a desk lamp $(1000 \mathrm{~lx})$. The smaller compartment $(14 \mathrm{~cm}$ long) was close-topped and painted black. Mice were individually placed in the center of the light compartment, facing away from the partition, and allowed to freely explore the apparatus for $10 \mathrm{~min}$. The number of light $\leftrightarrow$ dark transitions between the two compartments, and the total time spent in the dark compartment, were automatically recorded via photocells located at the opening between compartments, connected to a custom-built data analyzer (Bruce Smith and colleagues, Research Services Branch, National Institute of Mental Health, Bethesda, MD, USA).

\section{Emergence Test}

The emergence test was conducted as previously described (Takahashi et al, 1989; Smith et al, 1998; Holmes et al, 2003). The apparatus consisted of an opaque black Plexiglas cube $\left(16 \times 16 \times 19 \mathrm{~cm}^{3}\right)$ with an exit $\left(6 \times 4 \mathrm{~cm}^{2}\right)$ on one side at floor level. This 'shelter' was placed within an open field $\left(40 \times 40 \times 35 \mathrm{~cm}^{3}\right)$, brightly illuminated by overhead fluorescent lighting $(550 \mathrm{~lx})$, with the exit facing out into the open field (parallel with one wall of the open field). Mice were first placed inside the shelter, with the exit closed, for a 5 min habituation period. After the habituation period, the exit was opened to allow the mouse to leave the shelter and explore the open field for $5 \mathrm{~min}$. The latency to emerge from the shelter, time spent out of the shelter and shelter $\leftrightarrow$ open field transitions were recorded by an experienced observer using behavioral scoring software (Hindsight, Scientific Programming Services, Wokingham, UK).

\section{Open Field Test}

The open field test was conducted as previously described (Mathis et al, 1994; Holmes et al, 2001, 2003; Miyakawa et al, 2001). The open field was a square arena $\left(40 \times 40 \times 35 \mathrm{~cm}^{3}\right)$ with clear Plexiglas walls and floor, brightly illuminated by overhead fluorescent lighting (550 lx). Mice were placed in the center of the open field and left to freely explore for a 30 min test session. Activity was measured by a computerassisted Digiscan optical animal activity system (RXYZCM, Omnitech Electronics, Accuscan, Colombus, OH). To detect horizontal activity, 16 photocell beams are positioned $1.5 \mathrm{~cm}$ above the floor. To detect vertical activity, eight photocell beams are positioned $7.5 \mathrm{~cm}$ above the floor. Center time is defined as the percent time spent in the central $20 \times 20 \mathrm{~cm}^{2}$ area of the open field.

\section{Effects Of Way 100635 In The Elevated Plus Maze}

Experimentally naïve female mice were tested for the effects of the $5-\mathrm{HT}_{1 \mathrm{~A}}$ receptor antagonist, WAY 100635, in the elevated plus maze. Mice were injected with either vehicle or $0.05,0.1$, or $0.3 \mathrm{mg} / \mathrm{kg}$ WAY 100635 , and tested on the elevated plus maze $30 \mathrm{~min}$ later using the same procedure as described above.

\section{Drugs}

WAY 100635 ( $N$-\{2-[4-(2-methoxyl)-1-piperazinyl]ethyl $\}-N$ (2-pyridinyl) cyclohexanecarboxamide trihydrochloride) (Wyeth Research, Monmouth Junction, NJ, USA) was freshly dissolved in distilled water, which also served as an inert vehicle. Vehicle or $0.05,0.1$, or $0.3 \mathrm{mg} / \mathrm{kg}$ WAY 100635 was injected subcutaneously $30 \mathrm{~min}$ prior to testing, in a volume of $10 \mathrm{mg} / \mathrm{kg}$ body weight. Doses of WAY 100635 were chosen on the basis of pilot studies in 5-HTT null mutant mice and $+I+$ controls and previous reports of the anxiety-related effects of this drug in mice (Collinson and Dawson, 1997; Cao and Rodgers, 1997b; Griebel et al, 1999, 2000).

\section{Statistical Analyses}

Statistical analyses were conducted using StatView software (SAS Institute Inc., Cary, NC, USA). Males and females were tested as separate groups and, therefore, not statistically compared. The effect of genotype was analyzed using analysis of variance (ANOVA). Open field horizontal activity was analyzed by two-factor ANOVA (genotype $\times$ time), with repeated measures for the factor of time, and Newman-Keuls post hoc tests where appropriate. For drug studies, the effects of genotype and WAY 100635 were analyzed using two-factor ANOVA (drug $\times$ genotype), and Newman-Keuls post hoc tests where appropriate. Statistical significance was set at $p<0.05$. 


\section{RESULTS}

\section{Elevated Plus Maze}

Elevated plus-maze results are presented in Figure 1. There was a significant effect of genotype for percent open arm time $(\mathrm{F}(2,40)=3.31, p=0.05)$ and percent open arm entries $(\mathrm{F}(2,40)=3.89, p=0.03)$, but not closed arm entries or rears (both $p>0.05$ ) in female mice. Newman-Keuls post hoc analysis showed that female 5-HTT $-/-$ mice spent significantly less time $(p<0.05)$ and made fewer entries $(p<0.05)$ into the open arms than $+/+$ littermates. In male mice, there was a significant effect of genotype for percent open arm time $(\mathrm{F}(2,41)=4.23, p=0.02)$, percent open arm entries $(\mathrm{F}(2,41)=9.37, p<0.001)$, and closed arm entries $(\mathrm{F}(2,41)=3.77, p=0.03)$, but not rears $(p>0.27)$. NewmanKeuls post hoc analysis showed that male 5-HTT $-/-$ mice spent significantly less time $(p<0.05)$ and made fewer entries $(p<0.01)$ into the open arms than $+I+$ littermates, while closed arm entries did not significantly differ between 5 -HTT $-I-$ mice and $+I+$ controls $(p>0.05)$.

\section{Light $\leftrightarrow$ Dark Exploration Test}

Light $\leftrightarrow$ dark exploration test results are presented in Figure $2 a$ and $b$. There was a significant effect of genotype for light $\leftrightarrow$ dark transitions $(\mathrm{F}(2,40)=7.92, \quad p<0.001)$ and percent time in the dark compartment $(\mathrm{F}(2,40)=17.12$, $p<0.001$ ) in female mice. Newman-Keuls post hoc analysis showed that female 5-HTT $-I-$ mice made significantly fewer light $\leftrightarrow$ dark transitions $(p<0.01)$ and spent significantly more time in the dark compartment $(p<0.01)$ than $+/+$ littermates. In male mice, there was a significant effect of genotype for light $\leftrightarrow$ dark transitions $(F(2,40)=9.22$, $p<0.001)$, but not percent time in the dark compartment $(\mathrm{F}(2,40)=1.97, p=0.15)$. Newman-Keuls post hoc analysis showed that male 5 -HTT $-I-$ mice made significantly fewer light $\leftrightarrow$ dark transitions $(p<0.01)$, than $+/+$ littermates.

\section{Emergence Test}

Emergence test results are presented in Figure $2 \mathrm{c}$ and $\mathrm{d}$. There was a significant effect of genotype for shelter $\leftrightarrow$ open field transitions $(\mathrm{F}(2,39)=5.39, p<0.01)$ and percent time out of the shelter $(\mathrm{F}(2,39)=23.92, p<0.001)$, but not latency to initially exit the shelter $(\mathrm{F}(2,39)=1.82, p=0.17$; data not shown) in female mice. Newman-Keuls post hoc analysis showed that female 5-HTT $-/-$ mice made significantly fewer shelter $\leftrightarrow$ open field transitions $(p<0.05)$ and spent less time out of the shelter $(p<0.05)$ than $+/+$ littermates. Female 5 -HTT $+/-$ spent less time out of the shelter $(p<0.01)$ than $+/+$ littermates. In male mice, there was a significant effect of genotype for shelter $\leftrightarrow$ open field transitions $(\mathrm{F}(2,41)=10.75, p<0.001)$, percent time out of the shelter $(\mathrm{F}(2,41)=22.01, p<0.001)$, and latency to exit the shelter $(\mathrm{F}(2,41)=10.51, p<0.001$; data not shown). Newman-Keuls post hoc analysis showed that male 5-HTT $-/-$ mice made significantly fewer shelter $\leftrightarrow$ open field transitions, spent less time out of the shelter, and took longer to initially exit the shelter (all $p<0.01)$, as compared to $+I+$ littermates.

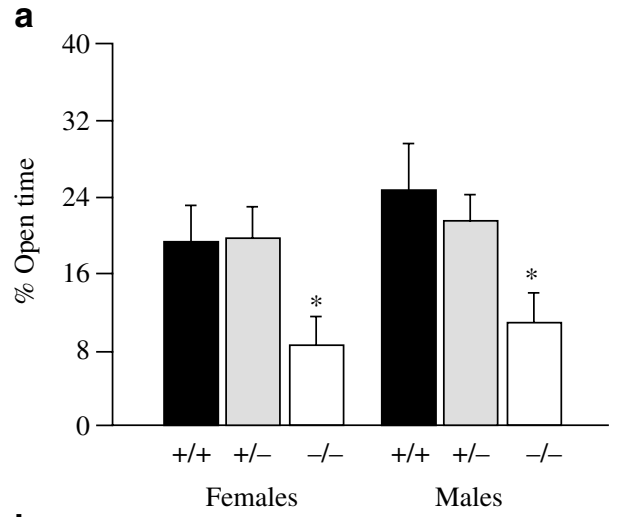

b

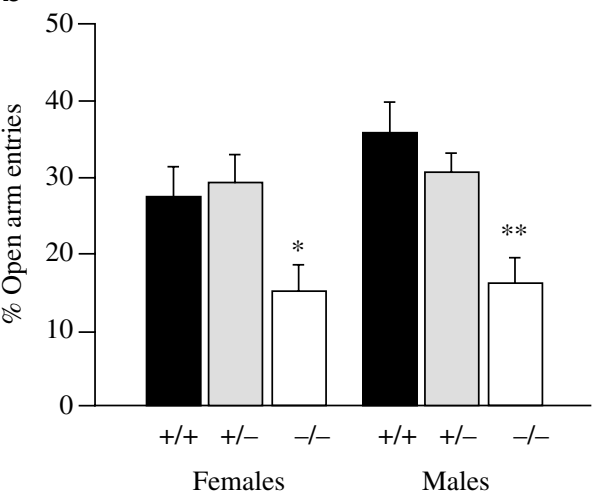

C

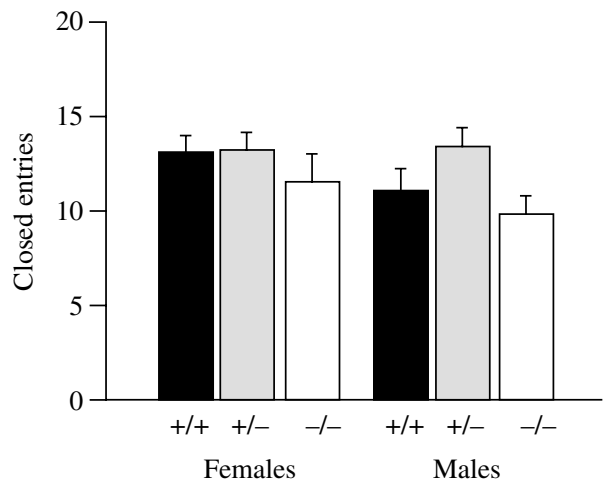

d

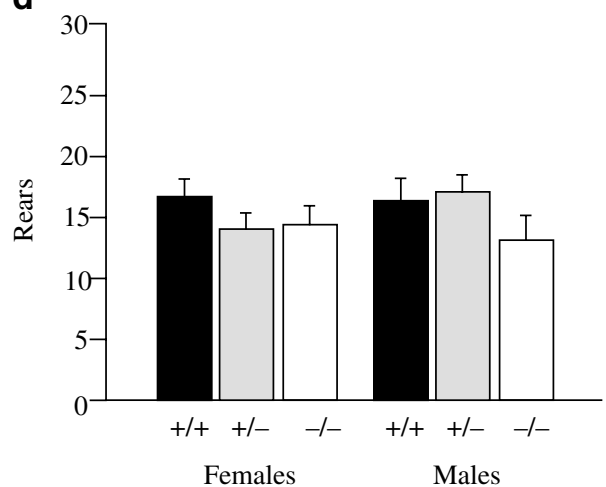

Figure I 5-HTT null mutant mice showed evidence of increased anxiety-like behavior in the elevated plus maze. 5-HTT - / - mice (a) spent less time and (b) made fewer entries into the aversive open arms than +1 + littermates, while measures of locomotor activity, (c) closed arm entries and (d) rears, were similar across genotypes. Data in Figures I-4 are means \pm SEM. Males and females were tested separately and, therefore, not statistically compared. $n=13-15$ females per genotype, $n=13-18$ males per genotype. *** $p<0.01$; ${ }^{*} p<0.05$ vs $+1+$ 
a

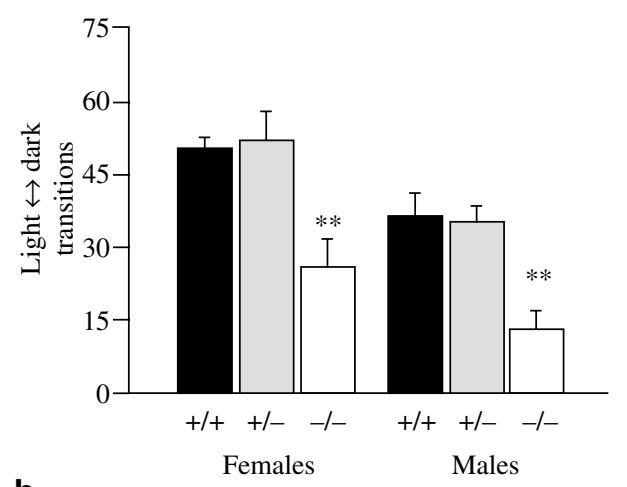

b

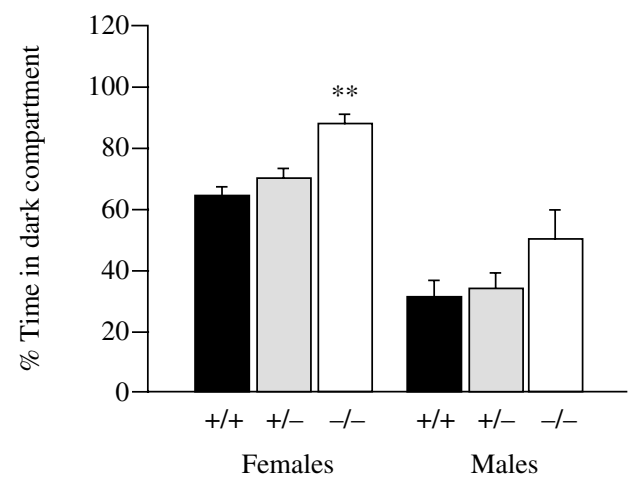

C
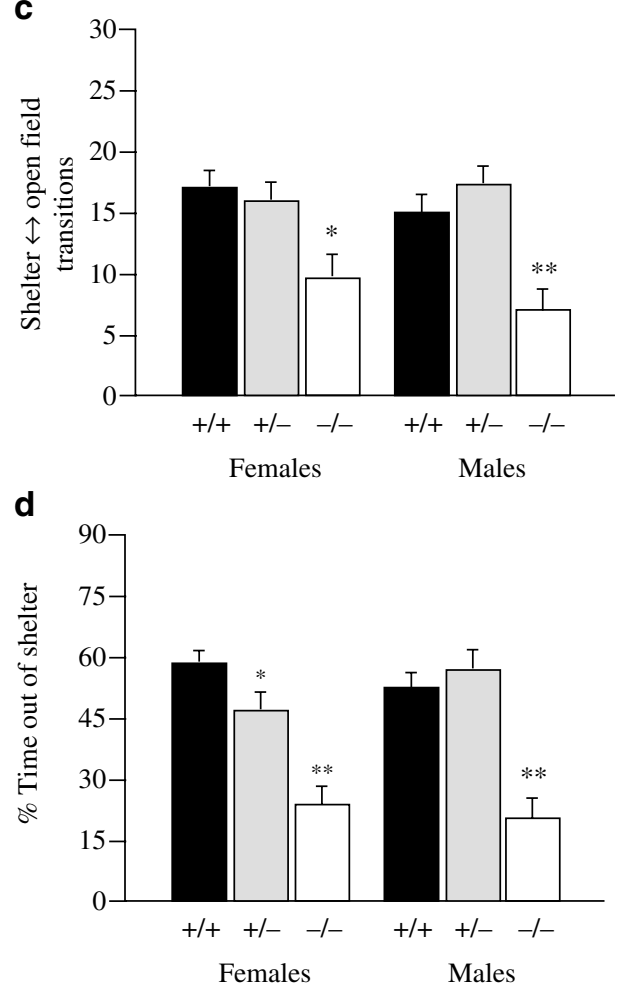

Figure $25-\mathrm{H} T$ null mutant mice showed abnormal exploratory locomotion and anxiety-like behaviors in the light $\leftrightarrow$ dark exploration and emergence tests. In the light $\leftrightarrow$ dark exploration test, 5-HTT -/ - mice (a) made fewer light $\leftrightarrow$ dark transitions and (b) spent less time in the dark compartment (females only) than $+1+$ littermates. In the emergence test, 5 -HTT $-/-$ mice (c) made fewer shelter $\leftrightarrow$ open field transitions and (d) spent less time out of the shelter (female $5-\mathrm{HTT}+I-$ also) than to $+1+$ littermates. $n=13-15$ females per genotype, $n=13-17$ males per genotype. ${ }^{*} p<0.01$; $* 00.05$ vs $+/+$.
Anxiety-like behaviors in serotonin transporter mutant mice A Holmes et al

\section{Open Field Test}

Open field test results are presented in Figure 3. There was a significant effect of genotype $(\mathrm{F}(2,39)=24.16, p<0.001)$ and time $(F(5,195)=19.71, p<0.001)$, but no genotype $\times$ time interaction $(\mathrm{F}(10,195)=0.61, p=0.81)$ for horizontal activity in female mice. Newman-Keuls post hoc tests showed that horizontal activity was generally lower in 5-HTT $-I-$ mice than $+I+$ controls $(p<0.01$ for data collapsed across the $30 \mathrm{~min}$ test session). There was a significant effect of genotype for vertical activity $(\mathrm{F}(2,39)=14.29, \quad p<0.001)$ and percent center time $(\mathrm{F}(2,39)=16.18, p<0.001)$ in female mice. Newman-Keuls post hoc tests showed that vertical activity $(p<0.01)$ and
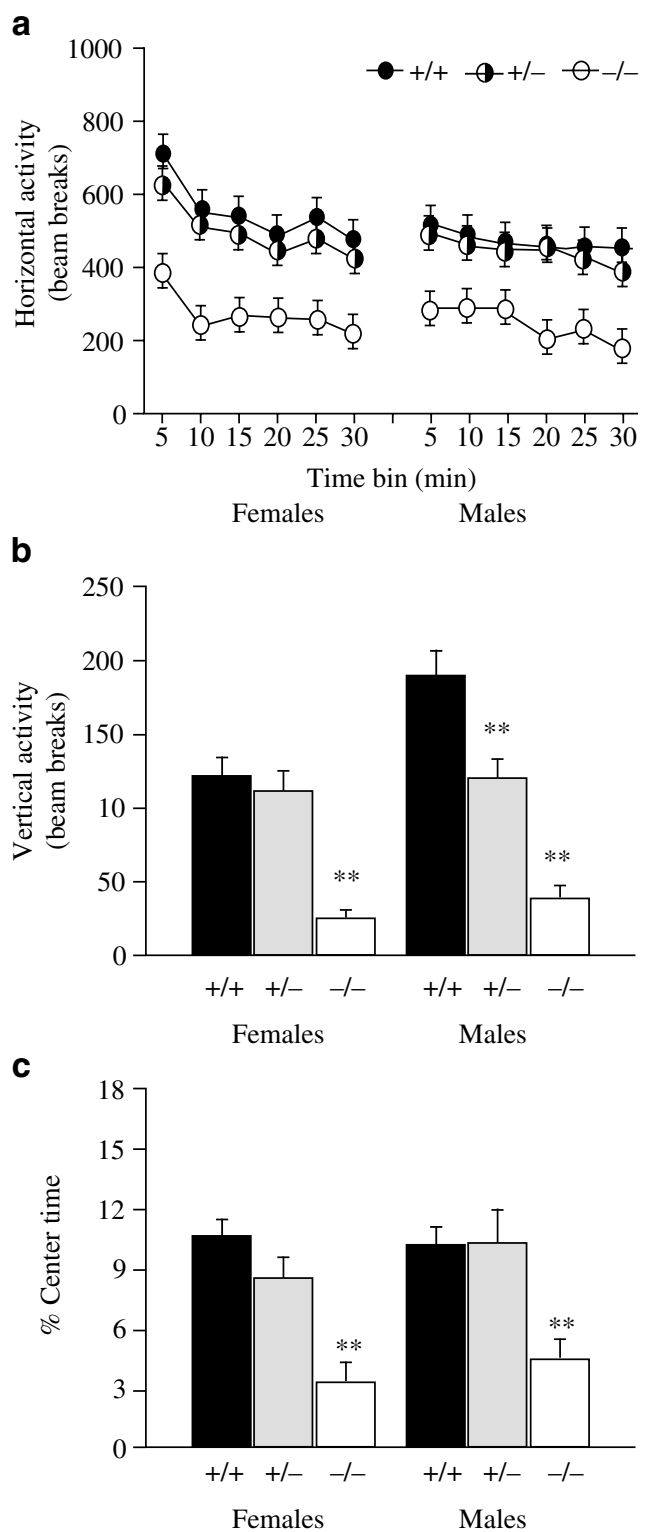

Figure 3 5-HTT null mutant mice showed abnormal exploratory locomotion and anxiety-like behaviors in the open field test. 5-HTT - /mice showed reduced (a) horizontal activity and (b) vertical activity (male $5-\mathrm{HTT}+/-$ also), and (c) showed increased avoidance of the center of the open field, as compared to $+1+$ littermates. $n=12-15$ females per genotype, $n=12-17$ males per genotype. ${ }^{*} * 0.01$ vs $+/+$. 
percent time in the center $(p<0.01)$ were both significantly lower in female 5 -HTT $-I-$ mice than $+/+$ littermates.

In male mice, there was a significant effect of genotype $(\mathrm{F}(2,39)=21.85, \quad p<0.001)$ and time $(\mathrm{F}(5,195)=5.04$, $p<0.001)$, but no genotype $\times$ time interaction $(\mathrm{F}(10,195)=0.54, p=0.86)$, for horizontal activity. Newman-Keuls post hoc analysis showed that horizontal activity was generally lower in male 5 -HTT $-I-$ mice than $+I+$ controls $(p<0.01$ for data collapsed across the $30 \mathrm{~min}$ test session). There was a significant effect of genotype for vertical activity $(\mathrm{F}(2,39)=26.35, p<0.001)$ and percent center time $(\mathrm{F}(2,39)=5.56, p<0.01)$. Newman-Keuls post hoc tests showed that vertical activity $(p<0.01)$ and percent center time $(p<0.01)$ were both significantly lower in 5 HTT $-I-$ mice than $+/+$ littermates, while vertical activity was also significantly lower in male 5-HTT $+I-$ mice than $+I+$ littermates $(p<0.01)$.

\section{Effects Of Way 100635 In The Elevated Plus Maze}

The effects of the 5- $\mathrm{HT}_{1 \mathrm{~A}}$ receptor antagonist WAY 100635 on elevated plus-maze behavior in female mice are shown in Figure 4. There was a significant interaction between genotype and drug on percent open arm time $(\mathrm{F}(6,121)=3.07, p<0.01)$, as well as significant main effects of the drug $(\mathrm{F}(3,121)=7.25, p<0.001)$ and genotype $(\mathrm{F}(2,121)=3.65, p=0.03)$. Newman-Keuls post hoc tests showed that WAY 100635 significantly increased percent open arm time in 5-HTT $-/-$ mice at all doses (all $p<0.01$ ), while the drug had no effect in 5 -HTT $+/-$ mice or $+/+$ littermates at any dose tested $(p>0.05)$. Percent open arm time was significantly lower in 5 -HTT $-/-$ than $+/+$ controls following vehicle treatment $(p<0.05)$, whereas at 0.05 and $0.3 \mathrm{mg} / \mathrm{kg}$ there were no differences between genotypes (both $p>0.05$ ), and at $0.1 \mathrm{mg} / \mathrm{kg}$ percent open arm time was significantly higher in 5 -HTT $-/-$ mice than $+I+$ controls $(p<0.01)$. The effects of WAY 100635 on percent open arm entries were also dependent upon genotype (drug $\mathrm{F} 3,121=8.93, \quad p<0.001$; genotype $\mathrm{F} 2,121=2.49, \quad p=0.09 ; \quad$ drug $\times$ genotype $\mathrm{F} 6,121=2.33$, $p=0.04)$. Newman-Keuls post hoc tests showed that WAY 100635 significantly increased percent open arm entries in 5 -HTT $-/-$ mice at all doses (all $p<0.01$ ), but had no effect in 5 -HTT $+I-$ mice $+I+$ controls at any dose tested (all $p>0.05)$. In addition, percent open arm entries were significantly higher in 5 -HTT $-/-$ than $+/+$ controls at $0.1 \mathrm{mg} / \mathrm{kg}$ WAY $100635(p<0.01)$, but not other doses $(p>0.05)$.

Figure 4 The 5-HT IA receptor antagonist, WAY 100635, produced anxiolytic-like effects in female 5-HTT - /- mice in the elevated plus maze. WAY 100635 (a) increased percent open arm time and (b) percent open arm entries in 5-HTT $-1-$ mice at all doses tested, but had no effect in $5-\mathrm{HTT}-1-$ mice or $+1+$ controls at any dose. Vehicle-treated female $5-\mathrm{HTT}-/$ - mice showed significantly less percent open arm time than $+/+$ controls (a). There was a significantly lower level of (c) closed arm entries and (d) rears in 5-HTT $-/-$ mice, as compared to $+/+$ controls, at all doses (except vehicle for closed arm entries). WAY 100635 decreased closed arm entries in 5-HTT $-1-$ mice at 0.1 and $0.3 \mathrm{mg} / \mathrm{kg}$ and in $+1+$ controls at $0.3 \mathrm{mg} / \mathrm{kg}$. WAY 100635 decreased rears at $0.3 \mathrm{mg} / \mathrm{kg}$ in $5-\mathrm{HTT}$ $+1-$ mice. $n=10-12$ per genotype, per dose. $* * * 0.01$; $* p<0.05$ vs same genotype treated with vehicle. \#\#p<0.01; \#p<0.05 vs $+1+$ treated with same dose.
There was a significant main effect of genotype $(\mathrm{F}(2,121)=12.56, p<0.001)$ and of drug $(\mathrm{F}(3,121)=6.17$, $p<0.001)$, but no significant drug $\times$ genotype interaction $(\mathrm{F}(6,121)=0.69, p=0.65)$, on closed arm entries. Newman-
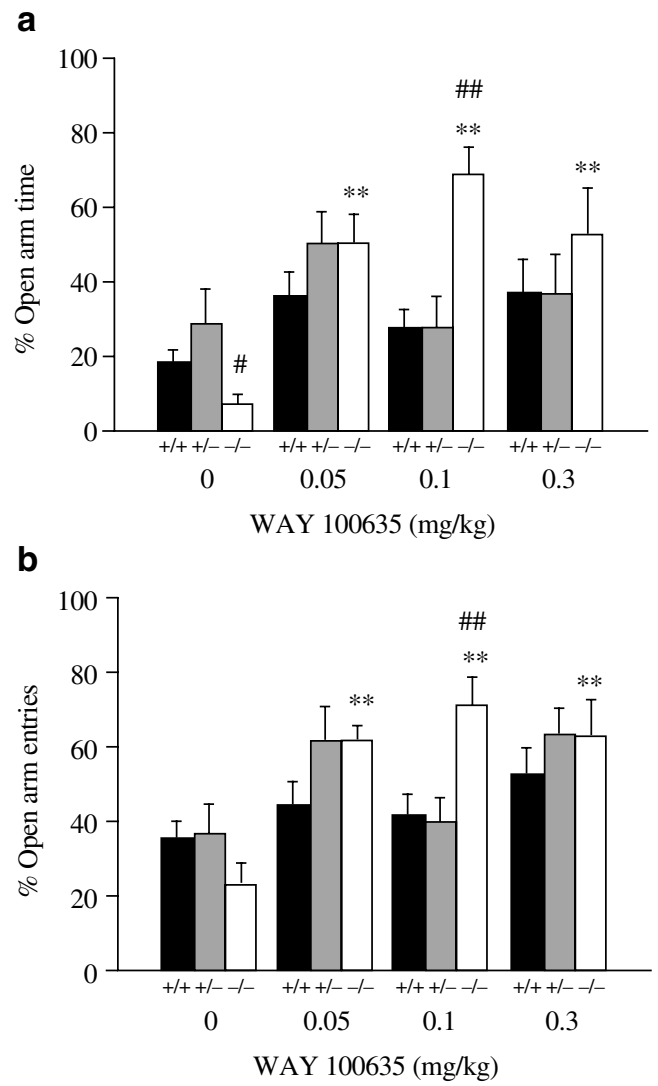

C

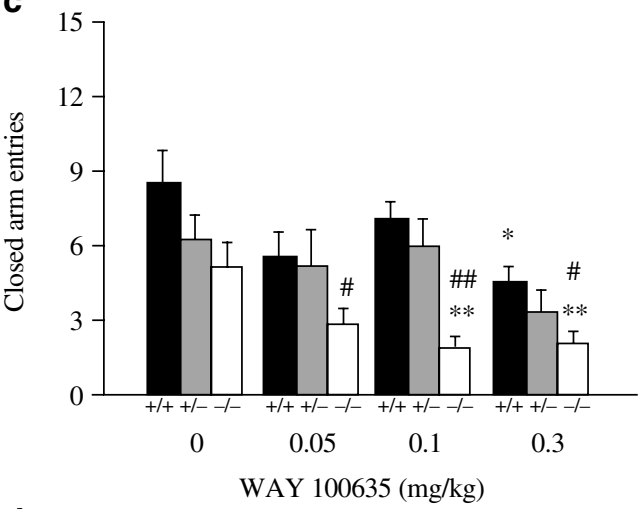

d

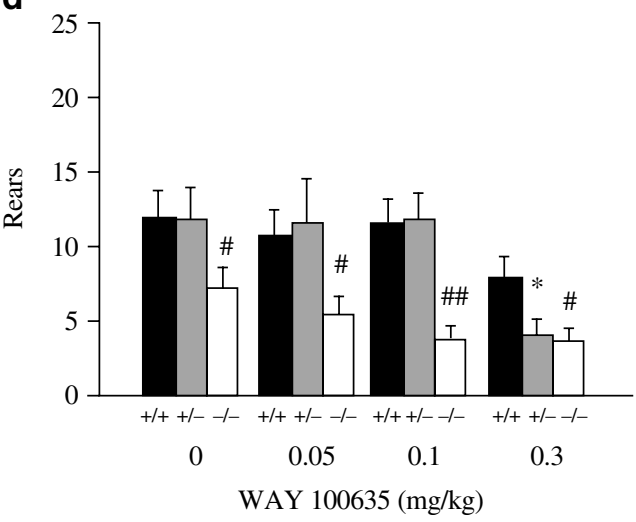


Keuls post hoc tests showed that WAY 100635 significantly decreased closed arm entries at 0.1 and $0.3 \mathrm{mg} / \mathrm{kg}$ (both $p<0.01)$ in 5 -HTT $-/-$ mice, and at $0.3 \mathrm{mg} / \mathrm{kg}$ in $+/+$ mice $(p<0.05)$. In addition, closed arm entries were significantly lower in 5 -HTT $-/-$ than $+/+$ littermates at $0.05(p<0.05), 0.1 \quad(p<0.01)$, and $0.3(p<0.05) \mathrm{mg} / \mathrm{kg}$ WAY 100635, but not vehicle. ANOVA found main effects of genotype $\quad(\mathrm{F}(2,121)=11.68, \quad p<0.001) \quad$ and drug $(\mathrm{F}(3,121)=5.31, \quad p<0.01)$, but no significant drug $\times$ genotype interaction $(\mathrm{F}(6,121)=0.96, p=0.46)$, on rears. Newman-Keuls post hoc tests showed that WAY 100635 significantly decreased rears in 5-HTT $+/-$ mice at $0.3 \mathrm{mg} / \mathrm{kg}(p<0.05)$, but had no effect in 5 -HTT $-/-$ mice or $+I+$ littermates at any dose tested (all $p>0.05$ ). In addition, rears were significantly lower in 5 -HTT $-/-$ mice than $+/+$ littermates at all doses tested (all $p<0.05$ ).

In confirmation of the genotype-specific anxiolytic-like effects of WAY 100635 on elevated plus-maze behavior, a separate batch of (male) 5-HTT $-/-$ mice were found to show a significant anxiolytic-like response to $(0.3 \mathrm{mg} / \mathrm{kg})$ WAY 100635 (ie increased percent open arm time and percent open arm entries relative to vehicle), while the drug was without effect in $+I+$ littermates (data not shown).

\section{DISCUSSION}

The present findings show that targeted disruption of the serotonin transporter (5-HTT) gene (htt,slc6a4) leads to abnormalities in anxiety-like behavior and exploratory locomotion in mice. Abnormal behavioral phenotypes in 5-HTT null mutant mice were confirmed using four separate tests for anxiety-like behavior and were evident in both males and females.

Blockade of the $5-\mathrm{HT}_{1 \mathrm{~A}}$ receptor, via acute treatment with the highly selective antagonist, WAY 100635, produced anxiolytic-like effects in 5-HTT $-I-$ mice, but not $+/+$ controls, suggesting a role for the $5-\mathrm{HT}_{1 \mathrm{~A}}$ receptor in mediating anxiety-related abnormalities in 5-HTT null mutant mice.

5-HTT null mutant mice demonstrated robust phenotypic abnormalities in the four tasks employed in our anxietyrelated behavioral test battery. In the elevated plus maze, 5 -HTT $-I-$ mice showed a greater avoidance of the aversive open arms than $+I+$ littermate controls, consistent with increased anxiety-like behavior in this test. Abnormal behavior was also found in $5-\mathrm{HTT}-1-$ mice in two tests that measure responses to light/dark conflict. In the light $\leftrightarrow$ dark exploration test, female 5 -HTT $-/-$ mice showed fewer transitions between light and dark compartments and spent more of the test session in the dark compartment than their $+I+$ littermates. Male 5-HTT $-I-$ mice also showed relatively few intercompartmental transitions, but did not show a heightened preference for the dark compartment. The absence of an anxiety-like bias for the dark compartment in male 5 -HTT $-/-$ mice reflects the fact that $\sim 40 \%$ of these mice displayed complete behavioral inhibition when placed in the light compartment at the start of the test session, which skewed scores to show a false light compartment preference. The emergence test is less likely to be confounded by behavioral inhibition caused by pre- cipitous exposure to an aversive light area, because mice are initially placed within a protected, darkened shelter prior to the light/dark conflict phase. In the emergence test, both male and female 5-HTT - I- mice showed reduced exploration and an overall avoidance of a brightly illuminated arena, as compared to $+/+$ littermates.

In exploration-based tests for anxiety-like behavior, such as the light $\leftrightarrow$ dark exploration or emergence tests, it can be difficult to dissociate a strong anxiety-like phenotype from an impairment in exploratory locomotion per se, as both can manifest as an inhibition of exploratory locomotion (Blanchard et al, 1990; Crawley, 2000; File, 2001; Holmes, 2001; McNaughton and Gray, 2000). In this context, 5-HTT $-/-$ mice were no different from $+/+$ controls on independent measures of locomotor activity (ie entries and rears in the protected closed arms) in the elevated plus maze, under baseline conditions. This profile is consistent with a selective increase in anxiety-like behavior, rather than a more general deficit in locomotor activity, in 5-HTT $-I-$ mice in this test. However, importantly, profiles in other tests were more equivocal. For example, the behavior of 5-HTT $-I-$ mice in the open field would be consistent with either an increase in anxiety-like behavior (ie reduced center time) or deficient locomotor exploration (ie reduced horizontal and vertical activities). Moreover, we have previously found that 5 -HTT $-I-$ mice show lower levels of locomotor activity than their $+I+$ littermates in the home cage (Holmes et al, 2002a). Therefore, the most likely interpretation for the present results is that targeted disruption of the 5-HTT has adverse pleiotropic consequences for both anxiety-like behavior and exploratory locomotion. In order to further understand the precise nature of the behavioral abnormalities in 5-HTT null mutant mice, it will be of critical importance to assess these mice on behavioral tasks that are not contingent upon normal exploratory locomotion (eg Vogel conflict test, fearpotentiated startle, fear-conditioned freezing).

Interestingly, 5-HTT $+I-$ mice were similar to $+I+$ controls on measures of anxiety-like behavior, with only minor exceptions. Abnormalities in exploratory locomotion in 5 -HTT $+I-$ mice were limited to specific measures under baseline conditions (ie lower open field vertical activity), but extended to additional measures under putatively more stressful test conditions (ie lower open field horizontal activity following saline injection). We have previously found that 5 -HTT $+I-$ mice exhibit reduced aggressive behavior that is limited to specific measures and test conditions (Holmes et al, 2002a). By contrast, 5-HTT $+I-$ mice exhibit clear perturbations in serotonergic homeostasis that are intermediate between profiles evident in 5-HTT $-I-$ mice and $+I+$ controls, including elevated extracellular serotonin, decreased dorsal raphe firing, and reduced $5-\mathrm{HT}_{1 \mathrm{~A}}$ receptor expression and function (Li et al, 1999, 2000; Gobbi et al, 2001; Mathews et al, 2000; Montanez et al, 2003). Thus, the present findings suggest that serotonergic dysfunction in 5-HTT $+/$ - mice may manifest as behavioral abnormalities only under challenging environmental conditions.

The neural mechanisms underlying abnormal anxiety-like behavior and exploratory locomotion may relate to alterations in serotonergic neurotransmission in 5-HTT null mutant mice. Studies using either in vivo microdialysis in 
striatum (Mathews et al, 2000) or in vivo chronoamperometry in the hippocampus (Montanez et al, 2003) have shown that 5-HTT null mutants exhibit an absence of transporter-mediated clearance and a clear increase in basal levels of extracellular serotonin. Increased extracellular serotonin would be expected to cause excess activity at postsynaptic serotonin receptors which, in turn, could underlie increased anxiety-like behaviors in 5-HTT -Imice (Iversen, 1984; Graeff et al, 1996). To test this hypothesis, we examined the effects of pharmacological blockade of serotonin receptors on anxiety-like behaviors in 5 -HTT null mutants. The initial focus of these studies was the $5-\mathrm{HT}_{1 \mathrm{~A}}$ receptor subtype, using the highly selective 5$\mathrm{HT}_{1 \mathrm{~A}}$ receptor antagonist, WAY 100635 (Forster et al, 1995; Fletcher et al, 1996). Converging lines of evidence implicate the $5-\mathrm{HT}_{1 \mathrm{~A}}$ receptor subtype in the mediation of both clinical anxiety (Lesch, 1991; Strobel et al, 2003; Rickels and Rynn, 2002) and anxiety-like behavior in rodents (Griebel, 1995; Canto-de-Souza et al, 2002; Griebel et al, 1999, 2000; Olivier et al, 1999; Gross et al, 2002; Nunes-de-Souza et al, 2002). For example, studies have shown that activation of postsynaptic $5-\mathrm{HT}_{1 \mathrm{~A}}$ receptors in the forebrain regions, including the septum and hippocampus, leads to WAY 100635-reversible increases in anxiety-like behavior in various tasks (Andrews et al, 1994; File et al, 1996, 2000; but see Menard and Treit, 1998; Cervo et al, 2000). Furthermore, administration of WAY 100635 alone into the hippocampus has anxiolytic-like effects in the mouseelevated plus maze under specific test conditions (Nunesde-Souza et al, 2002).

In the present study, acute, systemic treatment with WAY 100635 led to a complete reversal of the anxiety-like phenotype in 5-HTT $-I-$ mice in the elevated plus maze. In replication of our baseline study, vehicle-treated 5-HTT -I- mice showed higher levels of anxiety-like behavior than vehicle-treated $+I+$ controls, as demonstrated by significantly lower percent open arm time and a trend for lower percent open entries. In contrast, 5-HTT $-/-$ mice treated with 0.05 and $0.3 \mathrm{mg} / \mathrm{kg}$ WAY 100635 were no different from $+/+$ controls and actually showed a relatively anxiolytic-like profile following treatment with $0.1 \mathrm{mg} / \mathrm{kg}$ WAY 100635. These doses of WAY 100635 had no significant effect on plus-maze anxiety-like behavior in $+/+$ controls either in this experiment or in our pilot studies. At the doses presently tested, systemic administration of WAY 100635 and other selective antagonists, such as mPPI, has been found to exert anxiolytic-like effects in the various rodent tasks, including the elevated plus maze, in some studies (eg Cao and Rodgers, 1997a, b; Griebel et al, 1999, 2000), but not others (eg File et al, 1996; Collinson and Dawson, 1997; Mendoza et al, 1999; Hata et al, 2001; for reviews see Griebel, 1995; Cao and Rodgers, 1997a, b; Griebel et al, 1999). One possible reason for this variability is that the effects of $5-\mathrm{HT}_{1 \mathrm{~A}}$ receptor antagonists will depend upon basal serotonergic tone and baseline anxietylike behavior evoked in a given test situation, which will vary somewhat across laboratories (Rodgers and Cao, 1999). The present finding that WAY 100635 failed to reduce anxiety-like behavior in $+/+$, but had marked anxiolyticlike effects in 5-HTT $-/-$ mice, would support this argument, given the increased extracellular serotonin the latter (Mathews et al, 2000; Montanez et al, 2003).
Motoric disturbances in the mouse-elevated plus maze have been found following treatment with WAY 100635, although usually at higher doses than those presently tested (Rodgers and Cole, 1994; Cao and Rodgers, 1997b; Griebel et al, 1999, 2000). At the highest dose tested $(0.3 \mathrm{mg} / \mathrm{kg})$, WAY 100635 reduced closed entries in both 5 -HTT $-I-$ mice and $+I+$ controls and rears in 5-HTT + I- mice. Therefore, this dose of WAY 100635 appeared to produce nonspecific motoric effects. There was a reduction in closed arm entries, but not rears, in 5-HTT $-/-$ mice treated with $0.1 \mathrm{mg} / \mathrm{kg}$ WAY 100635 . Given the absence of any behavioral effect of this dose in 5 -HTT $+I-$ mice or $+I+$ controls, this effect could reflect the fact that 5 -HTT $-/-$ mice showed very high $(\sim 70 \%)$ percent open arm time and percent open entries and, as such, had relatively little opportunity to explore the closed arms.

In our pharmacological experiment, 5-HTT $-/-$ mice exhibited a general decrease in closed arm entries and rears relative to $+I+$ controls. This contrasts with the normal locomotor activity observed in 5 -HTT $-/-$ mice in the elevated plus maze under baseline (ie no injection) conditions. Previous studies have found that prior exposure to stressors causes a general suppression of exploratory activity in various rodents tests for anxiety-like behavior (Kennett et al, 1987; Cheeta et al, 2000; Padovan and Guimaraes, 2000). In addition, we have previously found that 5 -HTT $-/-$ mice exhibit exaggerated neuroendocrine (plasma adrenocorticotropin) responses to injection stress, as compared to $+I+$ controls (Li et al, 1999). Thus, one possible explanation for reduced closed arm entries and rears in 5-HTT $-/-$ mice in the pharmacological, but not baseline, experiment is that there are genotype differences in the stress response to injection. However, in the absence of further studies that directly address this question, this profile is taken as further evidence of abnormal exploratory locomotion in 5-HTT null mutant mice. Interestingly, while WAY 100635 reversed anxiety-related measures of open arm exploration in 5-HTT $-1-$ mice, genotype differences in closed arm entries and rears were not normalized by the drug. These findings suggest that the $5-\mathrm{HT}_{1 \mathrm{~A}}$ receptor plays a major role in mediating increased anxiety-like behavior, but not abnormal exploratory locomotion, in 5-HTT null mutant mice.

The ability of WAY 100635 to produce anxiolytic-like effects in 5-HTT $-I-$ mice could be taken as evidence that abnormal anxiety-like behaviors in these mice are driven by increased extracellular serotonin acting at postsynaptic 5$\mathrm{HT}_{1 \mathrm{~A}}$ receptors. It should be noted that, while the number of somatodendritic 5- $\mathrm{HT}_{1 \mathrm{~A}}$ autoreceptor in raphe neurons is reduced $>50 \%$ in $5-\mathrm{HTT}-/-$ mice, postsynaptic $5-\mathrm{HT}_{1 \mathrm{~A}}$ receptor binding is only partially reduced in the hypothalamus, septum, and amygdala, and is not reduced whatsoever in the frontal cortex or hippocampus (Fabre et al, 2000; Li et al, 1999, 2000; Mannoury la Cour et al, 2001). Thus, although postsynaptic $5-\mathrm{HT}_{1 \mathrm{~A}}$ receptors are downregulated in some forebrain regions, reduced clearance and increased extracellular concentrations of serotonin in 5-HTT null mutant mice could still cause excess activation of postsynaptic $5-\mathrm{HT}_{1 \mathrm{~A}}$ receptors, and somehow contribute to the increased anxiety-like behavior and its reversal by WAY 100635 in these mice. 
However, there are a number of important caveats to this model. Firstly, 5- $\mathrm{HT}_{1 \mathrm{~A}}$ receptors are not only expressed as postsynaptic receptors in forebrain regions, but also act as somatodendritic autoreceptors in the dorsal and median raphe nuclei. Systemic administration of WAY 100635 will antagonize both populations of $5-\mathrm{HT}_{1 \mathrm{~A}}$ receptors. Gobbi et al (2001) have recently shown that systemic WAY 100635 causes a marked increase in serotonin dorsal raphe firing in 5 -HTT $-1-$ mice, at a dose that reduced anxiety-like behavior in the present study. Therefore, the net effect of WAY 100635 on serotonergic neurotransmission in 5-HTT $-/-$ mice may be more complex than originally anticipated. For example, increased serotonin neuronal firing induced by WAY 100635 in 5-HTT null mutants would be predicted to (1) increase activity at other serotonin receptors implicated in anxiety (eg $5-\mathrm{HT}_{2 \mathrm{C}}$ receptor; Martin et al, 1998) and, (2) alter activity at other neurotransmitter systems that are intimately associated with serotonin and the mediation of anxiety, such as norepinephrine (Szabo and Blier, 2001), corticotropin-releasing factor (Price et al, 1998), and substance P (Santarelli et al, 2001).

Secondly, analogous to the phenotypic profile of 5-HTT null mutant mice, chronic treatment with serotonin transporter uptake blockers leads to somewhat increased extracellular serotonin (Frazer and Daws, 1998) and a partial desensitization of $5-\mathrm{HT}_{1 \mathrm{~A}}$ receptors (Pineyro and Blier, 1999); yet these drugs are clinically effective anxiolytics. Furthermore, genetic disruption (antagonism) of the $5-\mathrm{HT}_{1 \mathrm{~A}}$ receptor causes increased anxiety-like behavior in mice, not the reverse (Heisler et al, 1998; Parks et al, 1998; Ramboz et al, 1998). These findings could lead one to predict that increased serotonergic neurotransmission acting through the $5-\mathrm{HT}_{1 \mathrm{~A}}$ receptor would reduce anxiety, rather than cause the increase in anxiety-like behavior seen in 5-HTT $-/-$ mice. However, the mechanisms underlying the anxiolytic effects of serotonin transporter uptake blockers are incompletely understood, while the basis of the anxiety-like phenotype in the $5-\mathrm{HT}_{1 \mathrm{~A}}$ receptor null mutant mice also appears to be more complex than initially thought. For example, Gross et al (2002) have recently found that inactivation of the $5-\mathrm{HT}_{1 \mathrm{~A}}$ receptor gene in adult mice does not affect anxiety-like behavior. Instead, their findings suggest that the anxiety-like phenotype in the $5-\mathrm{HT}_{1 \mathrm{~A}}$ receptor null mutant mice is caused by the absence of the receptor during a critical period of postnatal development. This important finding adds to a growing literature, demonstrating a central role for serotonin in the neurodevelopment of systems mediating emotion (Meaney et al, 1994; Levitt et al, 1997). The potential for neurodevelopment abnormalities affecting anxiety-like behavior in 5-HTT null mutant mice should not be underemphasized (Lesch and Mossner, 1998; Persico et al, 2001). Indeed, given the absence of the 5-HTT throughout ontogeny, 5-HTT null mutant mice provide a research tool for studying the potential long-term behavioral consequences of exposure to serotonin reuptake inhibitors during neurodevelopment.

5-HTT null mutant mice may also provide a model to study how genetic variation in the 5-HTT modulates human emotional responses. The short allele of a common polymorphism in the promoter region of the HTT causes reduced expression of the 5-HTT (Heils et al, 1996; Lesch et al, 1996; Little et al, 1998; Greenberg et al, 1999). Consistent with the finding that the genetic inactivation of the mouse 5-HTT gene leads to increased anxiety-like behavior, the low-expressing human 5-HTT polymorphism is associated with heightened trait anxiety/dysphoria, increased stress-reactive depression and exaggerated neural responses to fear (Lesch et al, 1996; Mazzanti et al, 1998; Greenberg et al, 2000; Hariri et al, 2002; Caspi et al, 2003). Our findings demonstrating that treatment with a $5-\mathrm{HT}_{1 \mathrm{~A}}$ receptor antagonist can normalize anxiety-like behavior in 5-HTT - /- mice, may suggest novel pharmacogenomic approaches to treating anxiety disorders associated with the low-expressing HTT variant.

In summary, the present findings show that genetic deletion of the serotonin transporter produced abnormalities in anxiety-like behavior across a battery of behavioral tests, along with reduced exploratory activity. Increased anxiety-like behavior, but not reduced exploratory locomotion, in 5-HTT $-/-$ mice was reversed by acute treatment with a $5-\mathrm{HT}_{1 \mathrm{~A}}$ receptor antagonist. The anxiety-like phenotype in 5-HTT $-I-$ mice adds to an emerging picture of abnormalities in 5-HTT null mutants across a range of behavioral, neuroendocrine, and physiological parameters associated with emotional disorders, including abnormal responses to stress (Li et al, 1999; Tjurmina et al, 2002), increased sensitivity to drugs of abuse (Uhl et al, 2002), impaired gastrointestinal motility (Chen et al, 2001), and disturbed REM sleep (Wisor et al, 2003). 5-HTT null mutant mice provide a model to investigate the role of the 5-HTT in mood and anxiety disorders.

\section{ACKNOWLEDGEMENTS}

The present research was supported by the National Institute of Mental Health Intramural Research Program and the Deutsche Forschungsgemeinschaft (SFB 581, Le 629/4-2). We thank Dr JE Barrett of Wyeth Research for the kind gift of WAY 100635.

\section{REFERENCES}

Andrews N, Hogg S, Gonzalez LE, File SE (1994). 5- $\mathrm{HT}_{1 \mathrm{~A}}$ receptors in the median raphe nucleus and dorsal hippocampus may mediate anxiolytic and anxiogenic behaviours, respectively. Eur J Pharmacol 264: 259-264.

Arango V, Underwood MD, Mann JJ (2002). Serotonin brain circuits involved in major depression and suicide. Prog Brain Res 136: 443-453.

Bale TL, Picetti R, Contarino A, Koob GF, Vale WW, Lee KF (2002). Mice deficient for both corticotropin-releasing factor receptor 1 (CRFR1) and CRFR2 have an impaired stress response and display sexually dichotomous anxiety-like behavior. $J$ Neurosci 22: 193-199.

Ballenger JC (1999). Current treatments of the anxiety disorders in adults. Biol Psychiatry 46: 1579-1594.

Bengel D, Murphy DL, Andrews AM, Wichems CH, Feltner D, Heils A et al (1998). Altered brain serotonin homeostasis and locomotor insensitivity to 3,4-methylenedioxymethamphetamine ('Ecstasy') in serotonin transporter-deficient mice. Mol Pharmacol 53: 649-655.

Blakely RD, Berson HE, Fremeau Jr RT, Caron MG, Peek MM, Prince HK et al (1991). Cloning and expression of a functional serotonin transporter from rat brain. Nature 354: 66-70. 
Blanchard DC, Blanchard RJ, Tom P, Rodgers RJ (1990). Diazepam changes risk assessment in an anxiety/defense test battery. Psychopharmacology 101: 511-518.

Briley MS, Langer SZ, Raisman R, Sechter D, Zarifian E (1980). Tritiated imipramine binding sites are decreased in platelets of untreated depressed patients. Science 209: 303-305.

Canto-de-Souza A, Luiz Nunes-de-Souza R, Rodgers RJ (2002). Anxiolytic-like effect of Way-100635 microinfusions into the median (but not dorsal) raphe nucleus in mice exposed to the plus-maze: influence of prior test experience. Brain Res 928: 5059.

Cao BJ, Rodgers RJ (1997a). Anxiolytic-like profile of $p$-MPPI, a novel 5HT1A receptor antagonist, in the murine elevated plusmaze. Psychopharmacology 129: 365-371.

Cao BJ, Rodgers RJ (1997b). Influence of 5-HT1A receptor antagonism on plus-maze behaviour in mice. II. WAY 100635, SDZ 216-525 and NAN-190. Pharmacol Biochem Behav 58: 593603.

Caspi A, Sugden K, Moffitt TE, Taylor A, Craig IW, Harrington HL et al (2003). Influence of life stress on depression: moderation by a polymorphism in the 5-HTT gene. Science 301: 386-389.

Cervo L, Mocaer E, Bertaglia A, Samanin R (2000). Roles of 5-HT 1 A receptors in the dorsal raphe and dorsal hippocampus in anxiety assessed by the behavioral effects of 8-OH-DPAT and S 15535 in a modified Geller-Seifter conflict model. Neuropharmacology 39: 1037-1043.

Charney DS, Nestler EJ, Bunney BS (1999). Neurobiology of Mental Illness. Oxford University Press: New York. 958pp.

Cheeta S, Kenny PJ, File SE (2000). The role of 5-HT1A receptors in mediating the anxiogenic effects of nicotine following lateral septal administration. Eur J Neurosci 12: 3797-3802.

Chen JJ, Li Z, Pan H, Murphy DL, Tamir H, Koepsell H et al (2001). Maintenance of serotonin in the intestinal mucosa and ganglia of mice that lack the high-affinity serotonin transporter: abnormal intestinal motility and the expression of cation transporters. $J$ Neurosci 21: 6348-6361.

Collinson N, Dawson GR (1997). On the elevated plus-maze the anxiolytic-like effects of the 5-HT(1A) agonist, 8-OH-DPAT, but not the anxiogenic-like effects of the 5-HT(1A) partial agonist, buspirone, are blocked by the 5-HT1A antagonist, WAY 100635. Psychopharmacology 132: 35-43.

Crawley JN (1981). Neuropharmacologic specificity of a simple animal model for the behavioral actions of benzodiazepines. Pharmacol Biochem Behav 15: 695-699.

Crawley JN (2000). What's wrong with my mouse? Behavioral phenotyping of transgenic and knockout mice. Wiley-Liss: New York. 368pp.

Fabre V, Beaufour C, Evrard A, Rioux A, Hanoun N, Lesch KP et al (2000). Altered expression and functions of serotonin 5-HT1A and 5-HT1B receptors in knock-out mice lacking the 5-HT transporter. Eur J Neurosci 12: 2299-2310.

File SE (2001). Factors controlling measures of anxiety and responses to novelty in the mouse. Behav Brain Res 125: 151157.

File SE, Gonzalez LE, Andrews N (1996). Comparative study of preand postsynaptic 5-HT1A receptor modulation of anxiety in two ethological animal tests. J Neurosci 16: 4810-4815.

File SE, Kenny PJ, Cheeta S (2000). The role of the dorsal hippocampal serotonergic and cholinergic systems in the modulation of anxiety. Pharmacol Biochem Behav 66: 65-72.

Fletcher EA, Forster DJ, Bill G, Brown IA, Cliffe IA, Hartley JE et al (1996). Electrophysiological, biochemical, neurochemical and behavioural studies with WAY 100635, a potent, selective and silent $5-\mathrm{HT}_{1 \mathrm{~A}}$ receptor antagonist. Behav Brain Res 73: 337-353.

Forster EA, Cliffe IA, Bill DJ, Dover GM, Jones D, Reilly Y et al (1995). Pharmacological profile of the selective silent $5-\mathrm{HT}_{1 \mathrm{~A}}$ receptor antagonist, WAY-100635. Eur J Pharmacol 281: 81-88.
Frazer A, Daws LC (1998). Serotonin transporter function in vivo: assessment by chronoamperometry. Ann NY Acad Sci 861: 217229.

Gobbi G, Murphy DL, Lesch KP, Blier P (2001). Modifications of the serotonergic system in mice lacking serotonin transporters: an in vivo electrophysiological study. J Pharmacol Exp Ther 296: 987-995.

Graeff FG, Guimaraes FS, De Andrade TG, Deakin JF (1996). Role of 5-HT in stress, anxiety, and depression. Pharmacol Biochem Behav 54: 129-141.

Greenberg BD, Li Q, Lucas FR, Hu S, Sirota LA, Benjamin J et al (2000). Association between the serotonin transporter promoter polymorphism and personality traits in a primarily female population sample. Am J Med Genet 96: 202-216.

Greenberg BD, Tolliver TJ, Huang SJ, Li Q, Bengel D, Murphy DL (1999). Genetic variation in the serotonin transporter promoter region affects serotonin uptake in human blood platelets. $A m \mathrm{~J}$ Med Genet 88: 83-87.

Griebel G (1995). 5-Hydroxytryptamine-interacting drugs in animal models of anxiety disorders: more than 30 years of research. Pharmacol Ther 65: 319-395.

Griebel G, Rodgers RJ, Perrault G, Sanger DJ (1999). Behavioural profiles in the mouse defence test battery suggest anxiolytic potential of $5-\mathrm{HT}_{1 \mathrm{~A}}$ receptor antagonists. Psychopharmacology 144: $121-130$.

Griebel G, Rodgers RJ, Perrault G, Sanger DJ (2000). The effects of compounds varying in selectivity as $5-\mathrm{HT}_{1 \mathrm{~A}}$ receptor antagonists in three rat models of anxiety. Neuropharmacology 39: 18481857.

Gross C, Zhuang X, Stark K, Ramboz S, Oosting R, Kirby L et al (2002). Serotonin1A receptor acts during development to establish normal anxiety-like behaviour in the adult. Nature 416: 396-400.

Hariri AR, Mattay VS, Tessitore A, Fera F, Goldman D, Egan MF et al (2002). Serotonin transporter genetic variation and the response of the human amygdala. Science 297: 400-403.

Hata T, Nishikawa H, Itoh E, Funakami Y (2001). Anxiety-like behavior in elevated plus-maze tests in repeatedly cold-stressed mice. Jpn J Pharmacol 85: 189-196.

Heils A, Teufel A, Petri S, Stober G, Riederer P, Bengel D, et al (1996). Allelic variation of human serotonin transporter gene expression. J Neurochem 66: 2621-2624.

Heisler LK, Chu H-M, Brennan TJ, Danao JA, Bajwa P, Parson LH et al (1998). Elevated anxiety and antidepressant-like responses in serotonin 5-HT1A receptor mutant mice. Proc Natl Acad Sci USA 95: 15049-15054.

Holmes A (2001). Targeted gene mutation approaches to the study of anxiety-like behavior in mice. Neurosci Biobehav Rev 25: 261273.

Holmes A, Hollon TR, Liu Z, Sibley DR, Dreiling J, Gleason TC et al (2001). Dopamine D5 receptor null mutant mice show attenuated behavioral responses to a dopamine agonist. Behav Neurosci 115: 1129-1144.

Holmes A, Kinney JW, Wrenn CC, Li Q, Yang RJ, Ma L et al (2003). Galanin GAL-R1 receptor null mutant mice display increased anxiety-like behavior specific to the elevated plus-maze test. Neuropsychopharmacology 28: 1031-1044.

Holmes A, Murphy DL, Crawley JN (2002a). Reduced aggression in mice lacking the 5-HT transporter. Psychopharmacology 161: 160-167.

Holmes A, Rodgers RJ (1998). Responses of Swiss-Webster mice to repeated plus-maze experience: further evidence for a qualitative shift in emotional state? Pharmacol Biochem Behav 60: $473-488$.

Holmes A, Wrenn CC, Harris AP, Thayer K, Crawley JN (2002b). Behavioral profiles of inbred strains on novel olfactory, spatial and emotional tests for reference memory in mice. Genes Brain Behav 1: 55-69. 
Holmes A, Yang RJ, Crawley JN (2002c). Evaluation of an anxietyrelated phenotype in galanin overexpressing transgenic mice. $J$ Mol Neurosci 18: 151-165.

Holmes A, Yang RJ, Murphy DL, Crawley JN (2002d). Evaluation of antidepressant-related behavioral responses in mice lacking the serotonin transporter. Neuropsychopharmacology 27: 914-923.

Iversen SD (1984). 5-HT and anxiety. Neuropharmacology 23: $1553-1560$.

Kennett GA, Dourish CT, Curzon G (1987). Antidepressant-like action of 5-HT1A agonists and conventional antidepressants in an animal model of depression. Eur J Pharmacol 134: 265-274.

Kugaya A, Seneca NM, Snyder PJ, Williams SA, Malison RT, Baldwin RM et al (2003). Changes in human in vivo serotonin and dopamine transporter availabilities during chronic antidepressant administration. Neuropsychopharmacology 28: 413-420.

Lesch KP (1991). 5- $\mathrm{HT}_{1 \mathrm{~A}}$ receptor responsivity in anxiety disorders and depression. Prog Neuro-Psychopharmacol Biol Psychiatry 15: 723-733.

Lesch KP, Bengel D, Heils A, Sabol SZ, Greenberg BD, Petri S et al (1996). Association of anxiety-related traits with a polymorphism in the serotonin transporter gene regulatory region. Science 274: 1527-1531.

Lesch KP, Mossner R (1998). Genetically driven variation in serotonin uptake: is there a link to affective spectrum, neurodevelopmental, and neurodegenerative disorders? Biol Psychiatry 44: 179-192.

Lesch KP, Wiesmann M, Hoh A, T Müller, Disselkamp-Tietze J, Wiesmann $\mathrm{M}$ et al (1992). 5- $\mathrm{HT}_{1 \mathrm{~A}}$ receptor-effector system responsivity in panic disorder. Psychopharmacology 106: 111117.

Levitt P, Harvey JA, Friedman E, Simansky K, Murphy EH (1997). New evidence for neurotransmitter influences on brain development. Trends Neurosci 20: 269-274.

Li Q, Wichems C, Heils A, Lesch KP, Murphy DL (2000). Reduction in the density and expression, but not G-protein coupling, of serotonin receptors (5-HT1A) in 5-HT transporter knock-out mice: gender and brain region differences. J Neurosci 20: 78887895.

Li Q, Wichems C, Heils A, Van de Kar LD, Lesch KP, Murphy DL (1999). Reduction of 5-hydroxytryptamine (5-HT)(1A)-mediated temperature and neuroendocrine responses and 5-HT(1A) binding sites in 5-HT transporter knockout mice. J Pharmacol Exp Ther 291: 999-1007.

Li Q, Wichems C, Ma L, Van de Kar LD, Garcia F, Murphy DL (2003). Brain region-specific alterations in 5-HT2A and 5-HT2C receptors in serotonin transporter knockout mice. J Neurochem 84: $1256-1265$.

Lister RG (1987). The use of a plus-maze to measure anxiety in the mouse. Psychopharmacology 92: 180-185.

Little KY, McLaughlin DP, Zhang L, Livermore CS, Dalack GW, McFinton PR et al (1998). Cocaine, ethanol, and genotype effects on human midbrain serotonin transporter binding sites and mRNA levels. Am J Psychiatry 155: 207-213.

Malison RT, Price LH, Berman R, van Dyck $\mathrm{CH}$, Pelton GH, Carpenter L et al (1998). Reduced brain serotonin transporter availability in major depression as measured by [123I]-2 beta-carbomethoxy-3 beta-(4-iodophenyl)tropane and single photon emission computed tomography. Biol Psychiatry 44: 1090-1098.

Mannoury la Cour C, Boni C, Hanoun N, Lesch KP, Hamon M, Lanfumey L (2001). Functional consequences of 5-HT transporter gene disruption on 5-HT(1a) receptor-mediated regulation of dorsal raphe and hippocampal cell activity. J Neurosci 21: 21782185.

Martin JR, Bos M, Jenck F, Moreau J, Mutel V, Sleight AJ et al (1998). 5-HT2C receptor agonists: pharmacological character- istics and therapeutic potential. J Pharmacol Exp Ther 286: 913924.

Mathews TA, Fedele DE, Unger EL, Lesch KP, Murphy DL, Andrews AM (2000). Effects of serotonin transporter inactivation on extracellular 5-HT levels, in vivo microdialysis recovery and MDMA-induced release of serotonin and dopamine in mouse striatum. Soc Neurosci Abstr 26: 624.3.

Mathis C, Paul SM, Crawley JN (1994). Characterization of benzodiazepine-sensitive behaviors in the A/J and C57BL/6J inbred strains of mice. Behav Genet 24: 171-180.

Mazzanti CM, Lappalainen J, Long JC, Bengel D, Naukkarinen H, Eggert $M$ et al (1998). Role of the serotonin transporter promoter polymorphism in anxiety-related traits. Arch Gen Psychiatry 55: 936-940.

McNaughton N, Gray JA (2000). Anxiolytic action on the behavioural inhibition system implies multiple types of arousal contribute to anxiety. J Affect Disord 61: 161-176.

Meaney MJ, Diorio J, Francis D, LaRocque S, O'Donnell D, Smythe JW et al (1994). Environmental regulation of the development of glucocorticoid receptor systems in the rat forebrain. The role of serotonin. Ann NY Acad Sci 746: 260-273.

Menard J, Treit D (1998). The septum and the hippocampus differentially mediate anxiolytic effects of $R-(+)-8-O H-D P A T$. Behav Pharmacol 9: 93-101.

Mendoza DL, Bravo HA, Swanson HH (1999). Antiaggresive and anxiolytic effects of gepirone in mice, and their attenuation by WAY 100635. Pharmacol Biochem Behav 62: 499-509.

Miyakawa T, Yamada M, Duttaroy A, Wess J (2001). Hyperactivity and intact hippocampus-dependent learning in mice lacking the M1 muscarinic acetylcholine receptor. J Neurosci 21: 5239-5250.

Montanez S, Owens WA, Gould GG, Murphy DL, Daws LC (2003). Exaggerated effect of fluvoxamine in heterozygote serotonin transporter knockout mice. J Neurochem 86: 210-219.

Murphy DL, Li Q, Engel S, Wichems C, Andrews A, Lesch KP et al (2001). Genetic perspectives on the serotonin transporter. Brain Res Bull 56: 487-494.

Nemeroff CB, Knight DL, Franks J, Craighead WE, Krishnan KR (1994). Further studies on platelet serotonin transporter binding in depression. Am J Psychiatry 151: 1623-1625.

Nunes-de-Souza RL, Canto-de-Souza A, Rodgers RJ (2002). Effects of intra-hippocampal infusion of WAY-100635 on plus-maze behavior in mice. Influence of site of injection and prior test experience. Brain Res 927: 87-96.

Olivier B, Soudijn W, van Wijngaarden I (1999). The 5-HT1A receptor and its ligands: structure and function. Prog Drug Res 52: 103-165.

Padovan CM, Guimaraes FS (2000). Restraint-induced hypoactivity in an elevated plus-maze. Braz J Med Biol Res 33: 79-83.

Parks CL, Robinson PS, Sibille E, Shenk T, Toth M (1998). Increased anxiety of mice lacking the serotonin1A receptor. Proc Natl Acad Sci USA 95: 10734-10739.

Persico AM, Mengual E, Moessner R, Hall FS, Revay RS, Sora I et al (2001). Barrel pattern formation requires serotonin uptake by thalamocortical afferents, and not vesicular monoamine release. J Neurosci 21: 6862-6873.

Pineyro G, Blier P (1999). Autoregulation of serotonin neurons: role in antidepressant drug action. Pharmacol Rev 51: 533-591.

Price ML, Curtis AL, Kirby LG, Valentino RJ, Lucki I (1998). Effects of corticotropin-releasing factor on brain serotonergic activity. Neuropsychopharmacology 18: 492-502.

Ramamoorthy S, Bauman AL, Moore KR, Han H, Yang-Feng T, Chang AS et al (1993). Antidepressant- and cocaine-sensitive human serotonin transporter: molecular cloning, expression, and chromosomal localization. Proc Natl Acad Sci USA 90: 25422546.

Ramboz S, Oosting R, Amara DA, Kung HF, Blier P, Mendelsohn M et al (1998). Serotonin receptor 1A knockout: an animal model 
of anxiety-related disorder. Proc Natl Acad Sci USA 95: 14476-14481.

Rickels K, Rynn M (2002). Pharmacotherapy of generalized anxiety disorder. J Clin Psychiatry 14: 9-16.

Rioux A, Fabre V, Lesch KP, Moessner R, Murphy DL, Lanfumey L et al (1999). Adaptive changes of serotonin 5-HT2A receptors in mice lacking the serotonin transporter. Neurosci Lett 262: 113-116.

Rodgers RJ, Cao B-J (1999). Serotonin and anxiety: anxioselective effects of 5-HT1A receptor antagonists. In: Palomo T, Beninger $\mathrm{RJ}$, Archer $\mathrm{T}$ (eds). Interactive Monoaminergic Disorders. Editorial Sintesis, S.A.: Madrid. pp 47-63.

Rodgers RJ, Cole JC (1994). Anxiolytic-like effect of (S)-WAY 100135 , a $5-\mathrm{HT}_{1 \mathrm{~A}}$ receptor antagonist, in the murine elevated plus-maze test. Eur J Pharmacol 261: 321-325.

Santarelli L, Gobbi G, Debs PC, Sibille ET, Blier P, Hen R et al (2001). Genetic and pharmacological disruption of neurokinin 1 receptor function decreases anxiety-related behaviors and increases serotonergic function. Proc Natl Acad Sci USA 98: 1912-1917.

Smith GW, Aubry JM, Dellu F, Contarino A, Bilezikjian LM, Gold LH (1998). Corticotropin releasing factor receptor 1-deficient mice display decreased anxiety, impaired stress response, and aberrant neuroendocrine development. Neuron 20: 1093-1102.

Sora I, Hall FS, Andrews AM, Itokawa M, Li XF, Wei HB et al (2001). Molecular mechanisms of cocaine reward: combined dopamine and serotonin transporter knockouts eliminate cocaine place preference. Proc Natl Acad Sci USA 98: 5300-5305.

Stein DJ, Berk M (2000). Selective serotonin reuptake inhibitors in the anxiety disorders. Int Clin Psychopharmacol 15: 1-63.
Strobel A, Gutknecht L, Zheng Y, Brocke B, Lesch KP (2003). Allelic variation of Serotonin Receptor 1A function is associated with anxiety- and depression-related traits. (submitted).

Szabo ST, Blier P (2001). Functional and pharmacological characterization of the modulatory role of serotonin on the firing activity of locus coeruleus norepinephrine neurons. Brain Res 922: 9-20.

Takahashi LK, Kalin NH, Vanden Burgt JA, Sherman JE (1989). Corticotropin-releasing factor modulates defensive-withdrawal and exploratory behavior in rats. Behav Neurosci 103: 648-654.

Tjurmina OA, Armando I, Saavedra JM, Goldstein DS, Murphy DL (2002). Exaggerated adrenomedullary response to immobilization in mice with targeted disruption of the serotonin transporter gene. Endocrinology 143: 4520-4526.

Uhl GR, Hall FS, Sora I (2002). Cocaine, reward, movement and monoamine transporters. Mol Psychiatry 7: 21-26.

Vogel C, Mossner R, Gerlach M, Heinemann T, Murphy DL, Riederer P (2003). Absence of thermal hyperalgesia in serotonin transporter-deficient mice. J Neurosci 23: 708-715.

Willeit M, Praschak-Rieder N, Neumeister A, Pirker W, Asenbaum $\mathrm{S}$, Vitouch $\mathrm{O}$ et al (2000). $\left[{ }^{123} \mathrm{I}\right]$-beta-CIT SPECT imaging shows reduced brain serotonin transporter availability in drug- $=$ free depressed patients with seasonal affective disorder. Biol Psychiatry 47: 482-489.

Wisor JP, Wurts SW, Hall FS, Lesch KP, Murphy DL, Uhl GR (2003). Altered rapid eye movement sleep timing in serotonin transporter knockout mice. Neuroreport 14: 233-238.

Zhou FC, Lesch KP, Murphy DL (2002). Serotonin uptake into dopamine neurons via dopamine transporters: a compensatory alternative. Brain Res 942: 109-119. 